\title{
Human Rights, Gender Equality, and the Question of Justice: A Re-Examination of Male Chauvinism in African Culture
}

\author{
Rev. Fr. Dr. Hyginus Chibuike Ezebuilo
}

Department of Philosophy, Nnamdi Azikiwe University, Awka, Nigeria

frezebuilo@gmail.com

\begin{abstract}
Traditional cultural practices reflect the values and beliefs held by members of a community for periods of time. Every social grouping in the world has specific traditional cultural practices and beliefs, some of which are beneficial to all members, while others have become harmful to a specific group, such as women. These harmful and, sometimes, discriminatory traditional practices include early and forced marriages, virginity testing, widow's ritual, female genital mutilation, the primogeniture rule, and witch-hunting. Despite their harmful nature and their violation ofnational and international human rights laws, such practices persist because they are not questioned or challenged and therefore take on an aura of morality in the eyes of those practicing them. The purpose of this study is to discuss the impact of culture, tradition, customs, and law on gender equality in Africa. Applying the critical and analytic methods in philosophy, the study observes that law reform and development have traditionally focused on state legal institutions to the exclusion of customary legal system, and that where the courts had an opportunity to develop the customary legal system they either reinforced archaic customary laws or imposed Western ideology. This study further investigates, by means of interview in Nsukka part of Igbo-Africa, how ordinary men and women in Africa understand women's right, and how their attitudes are tied to local conception of masculinity. The investigation reveals that a new configuration of gender relations is evident in Africa - one that accommodates some aspects of women's rights while retaining previous notions of innate male authority. It concludes by showing that harmful traditional practices are unjust as they violate women's human rights (guaranteed in the Constitution), perpetuate the inequalities between women and men, and contribute to extreme poverty that government should fight to eradicate. Man and woman have the same dignity and are of equal value ontologically, and as such, we recommend that different African societies should uphold this ontological equality and dignity while socially constructing gender.
\end{abstract}

Keywords-Africa, culture, gender, women, rights.

\section{INTRODUCTION}

Culture is the way of life, especially the general customs and beliefs, of a particular group of people at a particular time. ${ }^{1}$ It is understood as a social domain that emphasizes the practices, discourses and material expressions, which, over time, express the continuities and discontinuities of social meaning of a life held in common. ${ }^{2}$ The revival of tradition, culture and custom is part of the new national and international identity; however, this revival must be rooted in a way of life based on human rights, democracy and equity for all, and understood from a point of view of igwebuike.
Much of this research involved unstructured time in the community talking with men and women in shops, bars, markets, on the streets, and in their homes. Our participant observation was complemented by additional qualitative research, including interviews and discussions. We categorized a range of ways people respond to these discourses, from the reactionary (gender inequality) to the mainstream (gender equity) to the transgressive (gender equality). ${ }^{3}$ Each of these responses reflects the prevailing hegemonic masculine ideal of being a provider and established notions of male authority in different ways. Reactionary responses reflect an established hegemonic masculinity and are premised on maintaining patriarchal 
power relations that frame men's power over women as natural and inevitable. Mainstream responses seek to reconcile men's 'power' role as the primary family provider and exclusive authority in the home with some aspects of women's rights. In this way, mainstream responses are not simply complicit with reactionary responses but instead represent, as Connell asserts, an emergent hegemonic masculinity that is still coalescing. ${ }^{4}$ Transgressive responses, in contrast, challenge hegemonic masculinities established and emergent - by being receptive to gender equality and reformulated ideas of men's roles and male authority.

Prior to this venture, we shall examine the influence of colonialism, imperialism, and apartheid on the African culture, traditions and customs with particular reference to Igbo people of Nigeria. This will include a brief review of what really constitutes African culture, tradition, and custom and their influence. It will be argued that the primogeniture rule (the primogeniture rule is the right, by law or custom, of a firstborn male to inherit the entire estate, to the exclusion of younger siblings) is not an original African cultural principle but a colonial and imperial construct. ${ }^{5}$ In our dialogue about the revival of our culture, tradition, and customs, we need to interrogate what is African and what is a colonial or imperial construct.

This paper is divided into six sections. The first is introduction, the second deals with the conceptual and theoretical framework, the third is a highlight of the concepts of gender and human rights, the fourth section attempts to situate our discussion within the context of Igbo-Africa. Section five contains a survey of some of the harmful and discriminatory cultural practices prevalent in different African societies, the sixth section attempts policy oriented advice through which contemporary African societies can promote gender equality and reduce injustices often meted to African women. Section seven concludes the paper.

\section{Conceptual and Theoretical Framework}

Culture is the social behaviors and norms found in different human societies. ${ }^{6}$ It comprises the range of phenomena that are transmitted through social learning in human societies. Some aspects of human behavior and social practices are said to be cultural universals, found in all human societies. These include culture-expressive forms such as music, dance, ritual, religion, and technologies such as tool usage, cooking, shelter, and clothing. The concept of material culture covers the physical expressions of culture, such as technology, architecture and art, whereas the immaterial aspects of culture such as principles of social organization (including practices of social organization, political organization, and social institutions), mythology, philosophy, literature (both written and unwritten), and science, comprise the immaterial/intangible cultural heritage of a society. ${ }^{7}$

In the words of E.B. Tylor, culture is 'that complex whole which includes knowledge, belief, art, morals, law, custom and any other capabilities and habits acquired by man as a member of society. ${ }^{8}$ Alternatively, culture is understood as a social domain that emphasizes the practices, discourses and material expressions, which, over time, express the continuities and discontinuities of social meaning of a life held in common. ${ }^{9}$ The Cambridge English Dictionary states that culture is the way of life, especially the general customs and beliefs, of a particular group of people at a particular time. ${ }^{10}$ The term is also used to denote the complex networks of practices and accumulated knowledge and ideas that are transmitted through social interaction and exist in specific human groups using the plural form.

In fact, there are as many definitions of culture as there are scholars who are interested in the phenomenon. Culture embraces a wide range of human phenomena, practices, material achievements and norms, beliefs, feelings, manners, morals and so on. It is the patterned way of life shared by a particular group of people that claims to share a single origin or descent. For this reason, Bello sees it as the totality of the way of life evolved by a people in their attempt to meet the challenge of living in their environment, which gives order and meaning to their social, political, economic, aesthetic and religious norms thus distinguishing a people from their neighbors. ${ }^{11}$ Affirming the notion that culture serves to distinguish a people from others, Aziza as serts that:

Culture...refers to the totality of the pattern of behavior of a particular group of people. It includes everything that makes them distinct from any other group of people; for instance, their greeting habits, dressing, social norms and taboos, food, songs and dance patterns, rites of passage from birth - through marriage - to death, traditional occupations, religious as well as philos ophical beliefs. ${ }^{12}$ 
It should be noted that culture is passed on from generation to generation. Thus, the acquisition of culture is a result of the socialization process. Throwing more light on this point, Aziza observes that the child just grows into and within the cultural heritage of the people and inhibits it. He made it clear that culture, in traditional society, is not taught but caught instead. The child, according to him, observes, imbibes and mimics the action of his elders and siblings. Therefore, it is impossible for the child in a traditional society to escape his cultural and physical environments ${ }^{13}$

The fact remains, however, that African culture has experienced rapid change since the colonial invasion. Hence, contemporary African culture is a mixture of traditional elements and alien features. Western cultures tend to be more individualistic and focused on individual achievements and personal interests, whereas African cultures are collective, group-oriented, and concerned with the welfare of their community. This is one African principle that colonialism and imperialism could not manipulate: ubuntu ${ }^{14}$ or igwebuike.

Igwebuike/ubuntu means I am what I am because of who we all are. These concepts underscore the importance of agreement or consensus. The overall concept of igwebuike or ubuntu values people as a community, rather than as individuals. This attitude has its strength and weakness anyway. The Zulus and other peoples have a saying, "umuntu ngumuntu ngabuntu," which means a person is a person through other persons. ${ }^{15}$ This same idea is conveyed in Igbo sayings: anyukoo amiri onu ogbaa ufufu (urine forms fume when we all urinate together in a common place); ofu osisi anaghi agba ohia (a single tree does not make forest) etc. It is a humanistic way of life which holds ethics and morals at the forefront of everything. All African cultural, traditional, and customary practices, including those pertaining to women and children, were based on igwebuike/ubuntu.

For this reason, the African traditional culture has an almost infinite capacity for the pursuit of consensus and reconciliation, as opposed to being individualistic and competitive. Further, in terms of African culture, there are no orphans because a child is a child of a community in which the child lived. Decision making in the African culture (as expressed in terms of the principle of igwebuike) is by consensus - productivity is optimized, not maximized, as the case may be in other cultures. Rewards are shared and so is suffering, as opposed to the context of an individualistic culture, where rewards are given according to individual merit and suffering is viewed as a penalty for one's carelessness. Sustainable competitive advantage comes from loyalty to group goals in terms of Igwebuike. But what does this mean in practice for a young girl who has to endure many harmful practices in the name of her culture? This same African tradition permits male chauvinism to the expense of their female counterparts who often fall victim of circumstances.

The idea of male superiority, meanwhile, is not peculiar to Africa. In several passages in the Summa Theologiae and elsewhere, Thomas Aquinas asserts the inferiority of women in both bodily strength and in force of intelligence. ${ }^{16}$ To top this off, he maintains that feminine intellectual inferiority actually contributes to the order and beauty of the universe. But he also affirms that in Heaven there are and will be women who occupy higher places than men. Perhaps, in this apparent inconsistency he is simply hedging on his seemingly chauvinistic positions to accommodate Mary, Queen of Heaven.

To begin to understand his position, we must ask why Aquinas thinks women intellectually inferior in the first place. Scripture is likely his first guide. St. Paul says in 1Corinthians 11:10 that "man was not created for the sake of woman, but woman was created for the sake of man." This passage echoes Genesis 2:18, 19: It is not good that the man should be alone. I will give him a helpmate."Aquinas reasons from these scriptural passages that when one thing exists for the sake of another, it is inferior to that other. Other passages indicate that women's inferiority is something divinely ordained. ${ }^{17}$ When in 1Corinthians 11:3 St. Paul says that "man is the head of woman," and in Ephesians 5:22 that "a husband is the head of his wife," Aquinas takes it as evident that if men are meant to rule, it can only be by virtue of intellectual superiority. ${ }^{18}$ Yet Aquinas says: "Just as some human beings will surpass certain angels in glory despite the inferiority of human nature to angelic nature, so too some women despite their inferiority as to intelligence." 19

Regardless of whether we agree with Aquinas' position, with all the inconsistencies, there is at least one important thing we can learn from him about relative inferiorities - we should love who we are. The beauty of nature lies in diversity. It is pride the excessive desire of our own excellence that tends to make us sad when another has perfection or grace we do not have. In our discussion of the differences between the sexes, we must avoid yielding to impulses of envy, but strive rather to love whatever we may have due to our sex. The problematic comes, however, 
when society takes undue advantage of natural diversity to suppress one class on the basis of sex or gender.

\section{Gender and Human Rights}

In the last few decades, notions of inalienable human rights have reshaped the political landscapes of countries throughout the developing world. Women's rights activists have been at the center of the revitalization of human rights, struggling to address gender inequality across cultures without lapsing into misguided sentiments. George ${ }^{20}$ observes that these changes are evident across the African continent, where the language of human rights has become integral to international declarations, regional treaties, national legislation, and grassroots activism. Many African constitutions explicitly recognize women's rights, and in 2003 the African Union passed the far-reaching Protocol on the Rights of Women in Africa. ${ }^{21}$

However, given this new salient issue of women's rights in Africa, there is surprisingly little research on how African men have understood these developments, and how African masculinities are implicated in such changes, hence, the need for this study.

The majority of men with whom we interacted in the course of this research were receptive to greater women's rights, so long as such changes did not undermine their ultimate authority over women, especially within the home. For such views, women's rights should be limited in scope and not synonymous with equality with men. However, some women and a small number of men we encountered did link women's rights to gender equality, and in the process they challenged entrenched notions of a masculinity rooted in male superiority. There was also a backlash to this new configuration because a minority of men we met were adamantly opposed to any notion of greater rights for men. This work, therefore, helps us understand how different engagements with human rights in local contexts are shaped by, and are shaping, gender relations. Importantly, human rights are not understood here as foreign to African societies, or as an imposition of 'Western' values in a 'nonwestern' setting. As Amartya Sen has argued, ${ }^{22}$ the constituent components of modern notions of human rights can be found in many cultures, not just Western cultures. While human rights may have found their fullest articulation in the West, the issues of human rights addresses fundamental questions about the relationship of the individual to society, and "thus is one that has been raised across time and across cultures." 23

African cultures, which are frequently essentialized as tradition-bound, communal, and incompatible with individual rights, have engaged with these issues as well. Many pre-colonial African societies articulated clear visions of human dignity, freedom from oppression, as well as rules governing the just distribution of goods.$^{24}$ While some have suggested that such African notions of human dignity and justice are not synonymous with human rights, ${ }^{25}$ these arguments presupposes a restricted, and rather Eurocentric, understanding of legally-enforceable, individual human rights. Such a narrow view obscures how many pre-colonial African societies espoused religious, moral, and cultural values that incorporated ideas of collective and individual rights - ideas that can validly be considered the contextual equivalent of the modern concept of legal rights.

With the formulation of the Organization of African Unity (OAU) in 1963, member states formally recognized the Universal Declaration of Human Rights. In 1981, the OAU expanded its recognition of human rights by adopting the African Charter on Human and People's Rights, which is unique in its inclusion of collective, or group, rights. ${ }^{26}$ While the African Charter does mandate that member states protect women's rights, some African women's rights activists argued that the emphasis on community rights gave legitimacy to cultural practices which discriminated against women.

\section{The Context of Igbo-Africa}

Interview research for this article was conducted in Nsukka, a low income community in Enugu, the capital of Enugu state of Nigeria. Like most Western African nations, Nigeria faces challenges in education, poverty reduction, and health care among others. Men dominate better-paying occupations, with men about twice as likely as women to be earning income through self-employment, and there are persistent gender gaps in literacy and education.

Although formal wage labor was virtually non-existent in Nsukka, some men found semi-regular work in Nsukka's auto-repair shops, metal workshops, butchers, farming, mason, and carpentry workshops. So Nsukka did provide men opportunities to earn money, even if the work was often strenuous, available only sporadically, and poorly paid. While men dominated the activity on Nsukka's commercial streets, women were present as well. Some worked in schools, pharmacies, office supply stores, or served food in restaurants or informal stalls. Off the main street, other women were earning money selling produce while they tended to their non-paid work at home.

Despite the economic hardships faced by residents of Nsukka, masculinity remains strongly tied to the breadwinner identity. In Nsukkas, there exists one dominant 
masculine ideal of being a provider, primarily embodied through responsible fatherhood. However, beyond this uncontested male provider ideal, there was much confusion and conflict over a set of contested masculine ideals related to work, male authority and male sexuality.

There are three main discourses regarding masculinity and gender relations. Gender inequality promotes the notion that men and women are different and unequal, with men being innately superior and, thus, in position of authority. Gender equity retains a notion that men and women are different but emphasizes that women should be afforded the same opportunities as men. Gender equality questions any innate male/female difference and is based on expansive notion of universal human rights that challenges naturalized ideas of male superiority and female subordination.

To gather our data, the method we employed involved unstructured time in the community talking with men and women in shops, bars, markets, on the streets, and in their homes. We categorized a range of ways people respond to these discourses, from the reactionary (gender inequality) to the mainstream (gender equity) to the transgressive (gender equality). Each of these responses reflects the prevailing hegemonic masculine ideal of being a provider and established notions of male authority in different ways.

The following sections focus primarily, but not exclusively, on how men understand these shifting gender discourses. The intention is not to reduce an analysis of masculinity to an examination of men's lives but instead to draw on men's perspectives to illuminate tensions between masculinity, women's rights, and gender equality in Nsukka.

Some men we met in Nsukka were hostile to the idea that men and women were equals. For some men, male physical and intellectual superiority was obvious and the conventional division of labor was a 'natural' outgrowth of such differences. Such understandings were often grounded in nature as a hardware shop manager explained: "This is natural; they are not equal, unless you want to change nature. They are influenced by nature; a woman cannot roof a house, she would require help from the man. The culture naturally does not allow such a thing to happen, especially here in Nsukka. But isn't gender a social construct assignment of roles? If it is why was it man that was favored? Perhaps it is also something natural.

Some men had a slightly softer edge to their patronizing attitude towards women. A well-respected butcher in Nsukka, saw men and women as complementing each other: "They are not equal. A man is higher because he is the one who goes out to bring the woman to his home. The man also is the major provider in the home. The relatives and inlaws have to look to the man for any requirements. But this does not mean that the man is too superior, however, because they complement each other.

Others echoed the same emphasis on male superiority being rooted in what they saw as men's long-standing roles as providers and leaders. As one man bluntly put it, "he in Nsukka they are not equal. Women do not control men, men control women. It does not change."

Discourses of gender equity and equality, however, challenges such entrenched ideas of male superiority and often elicited the deep sense of disempowerment and victimization many men felt. The following excerpt from a discussion with a group of four men makes this clear:

i. Women and men are not equal.

ii. A man should have been higher than the woman but now women are higher.

iii. Now, with equity, women will get to the same level as us because of the changing situation, but men are still higher.

iv. On the government's side, women and men are equal. When the women have money, women and men become equal.

Researcher: Do you think men and women should be treated equally?

i. They should both have been treated equally but the government has sided so much with the women.

ii. We men are so hurt.

iii. We should also advocate for our rights just as the women did...We are not equal, come what may, we shall never be equal.

For this group, perhaps, government programs advocating gender equity had gone too far and infringed on men's natural authority over women.

It was not just men who found shifting discourses on gender relations problematic. Some women were emphatic that men should have higher social status compared to women. "Men have more power and authority," said one woman, "and it should not change. They take on a lot of responsibility in the family, so they should have more power." Yet many of these women were also critical of men for abusing their power and dismiss suggestions that women's rights were now recognized and protected. As one woman puts it, "Men were given power by God, but they misuse it. A man can give any instruction and the women must follow it. A man's strength is greater than a woman's." 
In Nsukka, then, there were clearly elements of a backlash against women's rights and more egalitarian gender relations. Some reactionary men placed the blame on the government. For them, there was no distinction between gender equity and equality - both were problematic and threatened their already tenuous sense of authority.

Not all men in Nsukka were so reactionary. Some acknowledged albeit grudgingly, that some change was beneficial. Gender equity discourses had shaped the attitude of these men, and most were trying to reconcile gender equity with ideas of innate male authority. As one man said, "Men should have a special status according to culture. This status is inherited from our grandfathers and our fathers. But if it is to do with life, we should all be treated equally. For example, we are all entitled to medical treatment, whether a man or a woman...[But] I would be unhappy if women are given equal status to men.

Such view regards women and men as having different roles, and women fundamentally lower in status, but it recognized certain shared rights and the benefits of working collaboratively.

In Nsukka, we did encounter a few, mostly young men who wanted to explore more transgressive gender relations that accommodated ideas of gender equality. One such respondent replied:

From my own perspective, they are equal. Men and women are equal. But when it comes to responsibilities that is where the difference comes in: the gender roles or the way society vies men and women...But otherwise women and men are supposed to be the same, especially when it comes to rights.

Generally, it seems that while justice and equality are salient in Igbo Africa, the meaning is more restricted and does not imply an ontological equality of persons. It appears that gender equality by which we mean and women sharing power and cooperating to lead a family/society together is fundamentally incompatible with Igbo society and culture. Gender equity, which implies equal opportunity for women to gain power, is more compatible because it retains the notion of a single person at the head of any given level of society. In addition, the Igbo emphasis on individual achievement and social mobility, although conventionally related to men, may make certain aspects of advancing women's status through gender equity more culturally acceptable. However, the political advancement of women seems not to change the established relations of domestic hierarchy between husbands and wives. No doubt, then, Merry Sally Engle ${ }^{27}$ was right to note that local cultures are both potential barriers to and resources for social change.

Some Harmful and Discriminatory Cultural Practices in Africa

It does appear, as Igwilo and $\mathrm{Ogbo}^{28}$ rightly observes that while so-called African culture and values have positive, soul-lifting and humanistic dimensions, it also has some negative and dehumanizing aspects. Customary practices such as female genital mutilation, early and forced marriages, virginity testing, widow's rituals, breast sweeping/ironing, the primogeniture rule, and practices such as cleansing after male circumcision, witch-hunting, and other practices that impinge on gender equality, are entrenched, and in practice take precedence over equality in the in the villages where they are carried out. It is therefore questionable whether the constitutional protection of gender equality is making a difference to women living in communities with a strong commitment to traditional norms and practices. These compromises on women's right to equality can thus be interpreted to mean that women, as opposed to men, do not have inherent rights. In order to support this argument, we shall explore the impact of some of the above listed harmful practices.

The revival of traditions, culture, and customs, and the practices derived from them, after the demise of colonialism, imperialism and apartheid will definitely require us to enter into a dialogue on the character of our ancestors and what is really indigenous. ${ }^{29}$ However, the process should take the context into consideration. Some of the cultural practices that were necessary then are unnecessary now due to development, globalization and other factors. Below are some cultural practices that need to be scrutinized.

Virginity testing: virginity testing is practiced mostly in South Africa. ${ }^{30}$ Virginity testing is the practice and process of inspecting the genitalia of girls and women to determine if they are sexually chaste. ${ }^{31}$ It is based on the false assumption that a woman's hymen can be torn only as a result of sexual intercourse. It is a very controversial practice, both because of its implications for the girls tested and because it is not necessarily accurate.

The idea is that virginity testing is a form of sex education and it enforces abstinence from sexual activities before marriage. As Connell notes, girls are taught not to allow boys or men to take away their pride by having sexual 
intercourse with them before marriage. ${ }^{32}$ It is believed, then, that young women will abstain from sex because they fear being discovered to be no longer virgins. Now, the implication of this fear is problematic. This is a stigma not only for the girl but for her entire family. It is believed that virginity testing substantially reduces the spread of sexual transmitted diseases, including HIV/AIDS, and further, that it reduces teenage and unplanned pregnancies that lead to school dropouts. ${ }^{33}$

It appears then that the intention of the practice of virginity testing might be good, but its flip side is gender bias. It does not treat boy and girl children equally. It also has moral implications. Virginity testing poses a threat of discrimination against girl children who are not virgins (some of whom in many instances may have been raped). The reasons advanced for the practice do not focus on prevention and protection.

Widow's rituals: Widowhood is a clearly defined social role for women that is associated with prescribed institutionalized cultural and religious norms and the concomitant social sanctions if a deviation from the defined social role occurs ${ }^{34}$ However, an altogether different set of norms applies to men upon the death of their wives in many African societies. Evidence abound that there is large discrimination against widows, including the imposition of burdens, obligations or disadvantages, and the with-holding of benefits, opportunities or advantages, as well as the regular harassment of widows in the context of the household, community, state and market place. In fact, a woman's status shifts drastically (downward) after the death of her husband in contrast to the widower's status which remains unchanged (including in terms of the administration of the estate). A decrease in social status not only has implications for women's livelihood, economic status and quality life, but also increases their vulnerability to discrimination, abuse, harassment and gender-based violence, as well as their ability to assert their rights.

Both men and women experience increased social pressure during widowhood/widowerhood, but in different directions. Widows are pressured to remain 'loyal' and 'faithful' to their late husbands, and honour their memory, whereas men are often pressured into a quick remarriage, regardless of their readiness or wish to remarry. If widows remarry, they rarely do so of their own free will. In some communities widows may be forced into new conjugal relations with a male relative or be forbidden to remarry, even if they wish otherwise.
Witch-hunting: Witch hunting is a violence against women. It involves violence when one is branded a witch. Witchcraft violence against women has been a global problem since time immemorial. Connell remarks that it was practiced in Europe, as described by William Shakespeare in Macbeth, and till recently annual celebration of witches' day is, according to him, celebrated in Denmark. ${ }^{35}$ But the question remains, 'how do you identify and verify that someone is a witch?' Most of those blamed for witchcraft are elderly people and women. In igwebuike/ubuntu, old age or grey hair is a sign of wisdom and old people were respected, not abused, discriminated against or burned to death. The main ethical values of igwebuike/ubuntu are respect for others, including women and children, helpfulness, community, sharing, caring, trust and unselfishness. Morals such as compassion, cooperation and communalism are highly valued and the wellbeing of the whole community is a unified objective.

The patriarchal nature of our societies, as influenced and enhanced by colonialism and imperialism, explains why elderly women are targeted during witch-hunting. According to Connell, they are weak, defenseless and therefore easy targets. ${ }^{36}$ It is, therefore, criminal, and the perpetrators must face the full wrath of the law.

Female genital mutilation (FGM): Female genital mutilation is disfigurement that includes cutting of the clitoris. In some societies, it marks an important rite of passage into womanhood, while others believe it guarantees virginity, curbs female sexual desires, maintains hygiene, prevents promiscuity and increases fertility. ${ }^{37}$

Whatever the reason for practicing FGM, the consequences are a health hazard. The practice is normally performed without anaesthesia, using unhygienic methods and instruments. Its consequences include sickness or death due to infection, haemorrhage, blood poisoning. This is torture, and the prohibition against torture is contained in Nigerian Constitution, and article 5 of the African Charter on Human and Peoples' Rights. The Nigerian Constitution provides that every individual is entitled to respect for the dignity of his person, and accordingly, states that no person shall be subject to torture or to inhuman or degrading treatment. ${ }^{38}$

Primogeniture rule: The primogeniture rule is the right, by law or custom, of a firstborn to inherit the entire estate, to the exclusion of younger siblings. ${ }^{39}$ This rule, according to Kimmel Michael was not a customary law principle but a colonial and imperial construct imposed on Africans. ${ }^{40}$ The irony of it, however, is that African males embraced it as their customary principle because it benefitted them; 
therefore they are the ones who were fighting against its abolition. According to Kimmel, ${ }^{41}$ the rule was imposed on Africans in order for the state to be able to litigate against one person rather than to have to join the whole family when the head of the house died.

Twin killing: Prior to the arrival of Mary Mitchel Slessor (1848-1905) in Africa, ignorance, superstition, and negative values made multiple births to be seen as an abomination and a herald of evil. Although this practice was not exclusive to only women, there is no doubt that the woman who bore the child felt the pain most. Some of them ended up childless and may sometimes be sent out of her husband's family. Explaining how twins were looked at in those dark days, $\mathrm{Udo}^{42}$ notes that one of the twins was said to be genuine, the other an imposter. But by sharing the same cradle bed together, they were both infected and cursed. Their parents were equally guilty of defilement, particularly the mother.

The birth of twins was seen as a very bad omen in traditional Igbo-African society. In order to save the community from the anger and wrath of the deities, the twins were killed together - sometimes with their mothers. Since this barbaric custom was stopped by Mary Slessor, ${ }^{43}$ multiple births are now seen as multiple blessings. Members of the public freely make donations for their upkeep and we do not experience any wrath of those deities that demanded the heads of twins today. Twins have grown up to become normal, healthy, respected and respectable members of our society contributing economically, socially, morally, politically, religiously, and intellectually to the development of the African society. The custom had evolved from the practice of killing twin to recognizing that they are supernatural gifts.

\section{Promoting Gender Equality in Contemporary African Cultures}

As we have already observed, the idea of equal rights of men and women has been enshrined in the constitution of many African countries nowadays. The Nigerian Constitution of 1999, for instance, prohibits discrimination on the basis of sex and ensures that men and women have equal access in all civil matters. ${ }^{44}$ Explicit recognition of women's equal rights is contained in article 17[1] and [2](a). It recognizes equality of rights, obligations, and opportunities before the law. Article 11 states that women shall have equal rights as men with respect to employment opportunities, choice of professions, promotion and remuneration.
Similarly, speaking on gender equality, Pope Benedict XVI says:

The Church has the duty to contribute to the recognition and liberation of women,...Giving women opportunities to make their voice heard and to express their talents through initiatives which reinforce their worth, their selfesteem and their uniqueness would enable them to occupy a place in society equal to that of men...45

Now, gender refers to the roles of women and men of all ages, which are defined culturally, socially, economically and historically. These ideas vary across culture. 'Gender' itself is a term that evokes various debates and controversies. At a minimum, to the word 'gender' rather than 'sex' is to indicate that male and female roles in a given society are shaped not only by biology but by social practice, and that the role of women and men will not be identical in every society. ${ }^{46}$ In general terms, 'sex' refers to the biological differences between males and females, such as the genitalia and genetic differences, while gender can refer to the role of a male or female in society, or an individuals' conceptions of themselves in terms of identity. While a clear understanding of what we mean by gender and the difference between 'sex' and 'gender' is essential for policy development and practice, our motivation in prioritizing the gender dimension is rooted in the commitment to justice, solidarity and equality of women and men. We believe that gender equality is vital to the pressing need to tackle poverty and promote the development of wellbeing of the African communities. A deep commitment to justice and rejection of all forms of unfairness is at the core of genuine human society.

Indeed, the need for development calls for deliberate promotion of gender equality within Africa. In recent decades, there has been growing awareness in the development sector of the crucial significance of gender questions for both understanding and promoting development. Issues surrounding gender equality are therefore not peripheral but central for the achievement of development in Africa.

Firstly, poverty itself is not 'gender blind'. The situation of men and women in the poorest countries differ so that, by most measures, development outcomes are consistently worse for women than for men. 
Hence, Amartya Sen insists that confronting gender inequality involves transforming unequal power relations between men and women. ${ }^{47}$ In this context, promoting equal opportunities for women and men is a major priority. Restrictive attitude towards gender roles can lead to a denial of the basic human right of equality. As such stereotypical gender roles can prevent human development and social justice. Equal opportunities, Mamdani observes, means that men and women "have equal access to and control over resources and decision making process; enjoy equality under the law; have autonomy to make life choices free of violence." 48

Historically, interventions to promote development have not necessarily served African women and men equally. Because more men are employed in the formal economy in developing countries, more women are left outside of initiatives that promote labour rights, minimum wages, safe working conditions and so on. There is therefore an onus on governments and agencies to develop projects which will more explicitly target the development needs of women. The Catechism of the Catholic Church leaves no room for doubt: "Man and woman have the same dignity and are of equal value." 49 This is not merely a truth to be acknowledged but a statement that needs continuous and active promotion.

\section{CONCLUSION}

This paper is a re-examination of male chauvinism in African culture. Culture is like an umbrella under which some people like to hide from rain, and also to shade themselves from the sun. But sometimes you need to fold it. Every social grouping in the world has specific traditional cultural practices and beliefs, some of which are beneficial to all members, while others have become harmful to a specific group, such as women.

The paper investigated and condemns some unjust African traditional customs which deny identity and welfare to women. It examined the dictates of patriarchy that militate against female emancipation and lay a foundation for their marginalization and oppression. The study is a call for gender balance and equal treatment for men and women in a modern African society. It asserts that if modern Africa should experience a participatory socio-economic development it is urgent to end sexism and gender oppression in families and society, and to give men and women equal opportunities to emerge as fulfilled free beings

\section{REFERENCES}

[1] E.S.C. Weiner and J.E. Simpson, Oxford English Dictionary (2nd ed.) ( Oxford: Oxford University Press, 2004)

[2] James Magee et al., Urban Sustainability in Theory and Practice: Circles of Sustainability (London: Rutledge, 2015), p.53.

[3] Michael Kimmel, Men's responses to feminism at the turn of the century, Gender and Society, vol.1, no.1, 1987, p.261.

[4] P. Connell, Masculinities. Berkeley (University of California Press, 1995), p.79.

[5] Ibid. p.83.

[6] D. Igwilo and V.C. Ogbo, African Culture in a World of Change: A Philosophical Appraisal, Journal of African Studies and Sustainable Development, vol.1, no.3, 2018, p.29.

[7] J. Macioniss, and L. Gerer, Sociology (Toronto: Prentice Hall, 2011), p.53.

[8] E.B. Tylor, Primitive Culture: Research into the Development of Mythology, Philosophy, Religion, Language, Art and Custom (London: John Murray, 1974, p.1).

[9] James Magee, op.cit.

[10] E.S.C. Weiner and J.E. Simpson, op.cit.

[11] S. Bello, Culture and Decision Making in Nigeria (Lagos: National Council for Arts and Culture, 1991), p.189.

[12] R.C. Aziza, The relationship between language use and survival of culture: the case of Umuobo youth, Nigerian Language Studies, vol.1, no.4. 20001, p.31.

[13] Ibid. p.48.

[14] M. Chanock , Law, Custom and Social Order: the Colonial Experience in Malawi and Zambia (Cambridge: Cambridge University Press, 1985), pp.56-58.

[15] Ibid.

[16] I.G. Marrie, What Aquinas Really said about Women (New York: St Jogn's University Press, 1999), p.4.

[17] Ibid. p.46.

[18] Ibid. p.6.

[19] Ibid. p.47.

[20] Ibid. p.9.

[21] Ibid.

[22] A.K. Sen, Inequality Reexamined (Oxford: Oxford University Press, 1992), p.144.

[23] P.G. Lauren, The Evolution of International Human Rights (Philadelphia: University of Pennsylvania Press, 2003), p.23.

[24] M. Mamdani, The social basis of constitutionalism in Africa, Journal of Modern African Studies, vol.28, 2002. pp.359.

[25] J. Donnelly, Human rights and human dignity: An analytic critique of non-Western human rights conceptions, American Political Science Review, vol.76, 1982, pp.303.

[26] M. Mutua, "The Banjul Charter: The Case for an African Cultural Fingerprint," In An-Na'im A. (ed.), Cultural Transformation and Human Rights in Africa (London: Zed Books, 2002), PP.77-78. 
[27] S.e. Merry, Human Rights and Gender Violence: Translating International Law into Local Justice (Chicago: University of Chicago Press, 2006), P.19.

[28] D. Igwilo and V.C. Ogbo, op.cit. p.28.

[29] P. Connell, op.cit. p.43.

[30] Ibid.

[31] Ibid. p.44.

[32] Ibid. p.59.

[33] Ibid. p.60.

[34] Ibid.

[35] Ibid. p.47.

[36] Ibid. p.63.

[37] J. Donnelly, op.cit. p.212.

[38] cf. Section 34(1)(a), of the 1999 Constitution as amended.

[39] Michael Kimmel, op.cit.

[40] Ibid. p.6.

[41] Ibid. p.11.

[42] E. Udo, Mary Slessor in our time: HIV/AIDS, Sophia: An African Journal of Philosophy, vol.17, no.2, 2007, pp.103304.

[43] Ibid.

[44] Cf. Art.15[2] and art. 42[1] of the 1999 Constitution.

[45] Pope Benedict XVI, Africae Munus. Post synodal apostolic exhortation to the Bishops, Clergy, Consecrated persons and the lay faithful on the Church in Africa in service to reconciliation, justice and peace, 2011, part.1, ch.2.2.

[46] A.K. Sen, op.cit. p.101.

[47] Ibid.

[48] M. Mamdani, op.cit. p.55.

[49] Cited in I.G. Marrie, op.cit. 